Original Paper $\quad$ http://ajol.info/index.php/ijbcs $\quad$ http://indexmedicus.afro.who.int

\title{
Toxicity, cytotoxicity and biological activities of seeds of Carapa procera (DC), a native oil tree
}

\author{
Balé BAYALA ${ }^{1 *}$, Brahima SOW ${ }^{1}$, Vinsoun MILLOGO ${ }^{2}$, Youssouf OUATTARA ${ }^{1}$ et \\ Hamidou Hamadou TAMBOURA ${ }^{3}$ \\ ${ }^{1}$ Laboratoire de Physiologie Animale. UFR/Sciences de la Vie et de la Terre. Université Ouaga I Pr. Joseph \\ KI-ZERBO. 03 BP 7021 Ouagadougou 03 (BURKINA FASO). \\ ${ }^{2}$ Laboratoire de Recherche et d'Enseignement en Santé et Biotechnologie Animales/Institut du Développement \\ Rural/Université Polytechnique de Bobo-Dioulasso 01 BP 1091 Bobo-Dioulasso 01 (BURKINA FASO). \\ 3 Institut de l'Environnement et de Recherches Agricoles (INERA)/CNRST). Département Productions \\ Animales. UER/Biologie et Santé Animale. 01 BP 476 Ouagadougou 01 (BURKINA FASO). \\ *Corresponding author; E-mail: bayala_bale71@hotmail.com,Tel: (+226) 78823838.
}

\section{ACKNOWLEDGMENTS}

The present work was done with the support from DANIDA, Danish International Development Agency through QUALITREE project. This work was also supported by IAEA through the BKF5011-5014 project.

\begin{abstract}
Carapa procera is a native tree which seeds are intensively used for oil extraction. So this study deals with the identification of secondary metabolites, the toxicity and cytotoxicity of $C$. procera hydroalcohol extracts and their estrogenic and androgenic activities. The chemical constituents of $C$. procera extracts were determined by Thin Layer Chromatography (TLC) methods. The toxicity and cytotoxicity were respectively evaluated by the OECD Guideline 425 "Up and Down procedure" (UDP) and the brine shrimp lethality test. Estrogenic and androgenic activities were evaluated by uterotrophic and Hershberger tests and also by in vitro tests, with the yeast assay and MVLN luceferase assay. The $\mathrm{MeOH} / \mathrm{H}_{2} \mathrm{O}$ extracts of $C$. procera seeds revealed the presence of steroidal glycosides, triterpene, flavonoids and polyphenols. The DCM fraction revealed the presence of triterpene esters \& steroid and carotenoids. The $\mathrm{MeOH} / \mathrm{H}_{2} \mathrm{O}$ has, by in vivo tests, slight toxic effects with mice and shows a lethal effect against the crustacean larvae by in vitro test. The extracts of $C$. procera seeds also show, by in vivo and in vitro tests an estrogenic and anti-androgenic activities. The results show with the presence of flavonoids, polyphenols and glycosides steroids estrogenic and anti-androgenic activities. The seeds of $C$. procera contain some phytochemicals, which can disrupt or reinforce endocrine function.
\end{abstract}

(c) 2019 International Formulae Group. All rights reserved.

Keywords: Carapa procera, native oil tree, seeds, toxicity, estrogenic, antiandrogenic.

\section{INTRODUCTION}

In Burkina Faso, many native tree species are used for their potential composition in oil. For rural communities, these native oils increase and diversify their livelihoods. Women traditionally extract oil from native tree from seeds and this oil is an opportunity for diversification and income generation
(Ouédraogo et al., 2013; Tiétiambou et al., 2016).

Carapa procera (C. procera) is an oleaginous plant belongs to Meliaceae family which is very appreciated by traditional healers to treat various diseases. The oil from $C$. procera seeds is known to be used as food, cosmetics, veterinary medicine, insecticide and repellent properties (Guillemot, 2004). 
Regarding the importance of oil from $C$. procera seeds, there is a need to improve extraction method which is still unfortunately traditional. The rural community extraction is not able to purify the oil and several toxic substances have been reported, whereas it is known that some oleaginous plants contain hormone-like substances likely to possess an effect on animal reproduction function. Many phytochemical studies on the seeds of C. procera revealed the presence of flavonoids, phytosterols, triterpenes and tocopherols (Tindo et al., 2012; Goubgou, 2013). Some of these hormone-like substances can bind to the hormone receptor and interfere with endogenous hormone of human and animal reproduction function. Several works suggest the beneficial effects of phytoestrogen like protection against breast and prostate cancer. On the other hand, these compounds can also act as endocrine disrupters which could affect the endocrine system and may cause development and reproductive disturbances. For these reasons, there is a need to characterize the hormonal potency of natural compounds with the ability to bind to the estrogen (Diel et al., 2002).

Despite the highly sought and used of $C$. procera seeds for oil production very few studies have been interesting in the toxicity and the biological effects of these seeds extracts on animal reproductive function.

Due to the use of $C$. procera seeds for oil, the present study investigated the screening of phytochemicals in this seeds, the cytotoxicity, the acute toxicity and the effect of the seeds extracts on male and female reproductive tract by in vivo and in vitro tests.

\section{MATERIALS AND METHODS Plant material}

C. procera seeds were collected in 2015 between 6 and 10 am in West part of Burkina Faso. The seeds were identified by the Herbarium of Ouaga I Pr. Joseph KI-ZERBO University where a voucher sample was preserved for reference under number 6203.

\section{Animal material}

The NMRI mice, 27 days old were obtained from the animal house of Ouaga I Pr. Joseph KI-ZERBO University. The room temperature was maintained at $(22 \pm 3){ }^{\circ} \mathrm{C}$ with the $12 \mathrm{~h}$ light/12 $\mathrm{h}$ dark cycle and humidity at $50 \pm 10 \%$. The animals were fed with industrial pellets with $29 \%$ protein and have free access to drinking water. All tests included in the current work were performed according to the protocols already approved by the Department of Animal Physiology of Ouaga I Pr. Joseph KI-ZERBO University and met the international standards of animals study (Zimmermann, 1983).

\section{Chemical products}

Testosterone propionate (Purity 97\%) and the 17-béta-Estradiol (Purity 97\%) were purchased from the Sigma Chemical Co. (St. Louis, MO, USA).The DMSO 1\% was served as dilution liquid for the preparation of different doses. All substances were shipped and stored in glass containers at room temperature. All solvents were analytical grade.

\section{Extraction and isolation}

The dried and committed seeds of $\mathrm{C}$. procera $(100 \mathrm{~g})$ were successively extracted by maceration with dichloromethane $(8 \mathrm{~L})$ and methanol $(10 \mathrm{~L})$ at room temperature during 48 h. The extracts were concentrated to dryness under reduced pressure at $40{ }^{\circ} \mathrm{C}$ to yield dichloromethane (DCM) crude (3.5 g) and a methanol $(\mathrm{MeOH})$ residue $(100 \mathrm{~g})$. Both the extracts were dried and stored at $4{ }^{\circ} \mathrm{C}$ until used.

DCM crude $(1.5 \mathrm{~g})$ was fractionated by column chromatography over silica gel (40-63 $\mu \mathrm{m}$, Merck), eluted gradient (from $5 / 5$ to $0 / 10$, $\mathrm{v} / \mathrm{v}$ ), with / ethyl acetate gradient (from 5/5 to $0 / 10, \mathrm{v} / \mathrm{v}$ ) and afforded thirteen fractions (A to $\mathrm{M})$. Fraction $\mathrm{B}$ was purified by column chromatography over silica gel (40-63 $\mu^{\mathrm{m}}$, Merck), eluting with $\mathrm{n}$ - hexane/ethyl acetate gradient $(10 / 0$ to $7 / 3, \mathrm{v} / \mathrm{v})$ and yielded the compound $1 \quad(25 \mathrm{mg})$ and three 
other fractions. Fraction D was subjected to solid phase extraction (SPE) over silica gel (40$63 \mu^{\mathrm{m}}$, Merck) to yield compound 2 (6 mg) by using n-hexane/ethyl acetate $(0 / 10$ to with nhexane/ $\mathrm{CH}_{2} \mathrm{Cl}_{2} \mathrm{CH}_{2} \mathrm{Cl}_{2} 7 / 3$, v/v) as gradient.

The $\mathrm{MeOH}$ residue $(36 \mathrm{~g})$ was suspended in water $(600 \mathrm{~mL})$ during 20 hours, and partitioned with $\mathrm{CH}_{2} \mathrm{Cl}_{2}(3 \times 200 \mathrm{~mL})$ and fraction $(0.10 \mathrm{~g})$ and an ethyl acetate fraction $(1.03 \mathrm{~g})$. Ethyl acetate fraction was fractionated by column chromatography over Sephadex LH-20 (Pharmacia) as stationary phase and $\mathrm{MeOH}$ as eluent and afforded eight fractions (A.1 to A.8). Fraction A.3 was rechromatographied on silica gel $(40-63 \mu \mathrm{m}$, Merck) with n-hexane/ethyl acetate (6/4 to $0 / 10, v / v)$ as gradient and ethyl acetate $(3 \times 200$ $\mathrm{mL}$ ) to yield a $\mathrm{CH}_{2} \mathrm{Cl}_{2}$ yielded the compound 3 (27 mg). On the other hand, the screening of the chemical constituents was carried out with the extracts of the $C$. procera seeds, using chemical reagents and thin layer chromatography (TLC) methods according to the methodology suggested by Wagner and Bladt (2009).

\section{Acute toxicity test}

An intraperitoneal study for determining LD50 was performed according to the OECD Guideline 425 " $\mathrm{Up}$ and Down procedure" (UDP) (Bruce, 1985; OECD, 2001). In this method, animals were dosed once at a time. If the animal survived, the dose for the next animal was increased and if the animal died, the dose for the next animal was decreased. Six groups of 6 mice (control and test group), each containing an equal number of both male and female, were formed. The first group (control group) received distilled water. Groups 2-6 were intraperitonealy treated with hydro-alcoholic seeds extracts of $C$. procera at the doses of 250, 500, 750, 1000 and 3000 $\mathrm{mg} / \mathrm{kg}$ respectively. In each case the product volume administered by intraperitoneal was 1 $\mathrm{ml} / 100 \mathrm{~g}$ body weight. Following administration, the animals were observed for mortality or any sign of abnormality periodically during $1,24,48$ and $72 \mathrm{~h}$. The lethal dose (LD50) was estimated according to the method described by Litchfield and Wilcoxon (1949).

\section{Subchronic toxicity test}

Two groups of 10 mice, each containing an equal number of both male and female, received intraperitonealy during 28 consecutive days respectively distilled water (control groupe I) and $82 \mathrm{mg} / \mathrm{kg}$ (Group II). Mice were weighed every day before extracts administration and after a follow-up of 2 hours takes place to note signs of toxicity caused by the extract. Each mouse was marked with a unique identification number and behavior was observed daily during the trial period. One day after the last administration, all the mice were autopsied and the organs (lungs, heart, spleen, liver and kidney) were removed and weighed to note the necrotic signs.

\section{Brine shrimp lethality assay}

The bioactivity of the extracts was monitored by the brine shrimp lethality test (Meyer et al., 1982). Samples were dissolved in DMSO and diluted with artificial sea salt water so that final concentration of DMSO did not exceed $0.05 \%$. Fifty microliters of sea salt water were placed in all the wells of the 96-well microtiter plate. Fifty microliters $(1,10,100$, $1000 \mu \mathrm{g} / \mathrm{ml})$ seeds extracts were made in triplicate. Control wells with DMSO were included in each experiment. Hundred microliters of suspension of nauplii containing about 10 larvae was added into each well and incubated for $24 \mathrm{~h}$. The plates were then examined under a microscope (12.5×). $100 \mu \mathrm{l}$ of methanol was added in each well and after 15 min the number of dead nauplii in each well counted. Lethality concentration fifties (LC50 values) for each assay were calculated by taking average of three experiments using a Finney Probit analysis program (McLaughlin et al., 1991). 


\section{Uterotrophic and Hershberger tests}

Immature female mice, 24-27 days old, weighted $20 \pm 2 \mathrm{~g}$ were used for uterotrophic and Herhsberger tests. For each test, animals were divided into four groups, consisting of five mice each. The first group of each test served as a control and received distilled water. The second group of each test received $10 \mu \mathrm{g} / \mathrm{kg} \quad \mathrm{BW}$ of $17-\beta$-estradiol and Testosterone Propionate per day. The third and fourth group of each test received respectively 50 and $100 \mathrm{mg} / \mathrm{kg} \mathrm{BW}$ of $C$. procera hydroalcoholic seeds extracts. The different treatments were administered intraperitonealyduring three (3) consecutive days for Uterotrophic test and 10 consecutive days for Hershberger test. Twenty-four (24) hours after the last treatment, animal were weighed, sacrificed and autopsied. For Uterotrophic test, the uterus and ovaries were removed, separated from fat adhesions and weighed. The increase in uterine weight was taken as a measure of Uterotrophic activity. For Hershberger, testes, epididymis, seminal vesicles, prostate and levator ani muscle were removed, separated from fat adhesions and weighed. The increase of weight of accessory gland was taken as a measure of Hershberger test. Twenty-four (24) hours after the last treatment, animals were weighed, sacrificed and autopsied.

\section{Estrogen and androgen yeast assay}

The estrogen-inducible screening assay in the yeast strain $S$. cerevisiae was used as previously described (Routledge and Sumpter, 1997). Cells are stably transfected with the DNA sequence of the hER $\alpha$. The system also contains expression plasmids composed of two estrogen-responsive elements (ERE) regulating the expression of the reporter Lac- $Z$ gene that encodes the enzyme $\beta$-galactosidase (Sohoni and Sumpter, 1998).

Yeasts were handled as previously described (Tham et al., 1998). Stock solutions and the test compounds were prepared in DMSO and added to clear 96-well polystyrene plates (TPP, Switzerland), to a maximum concentration of $1 \%$ DMSO. Plates were seeded with $200 \mathrm{ml}$ per well of the assay medium; plates were then sealed and incubated at $32{ }^{\circ} \mathrm{C}$ for $2-3$ days. Substrate conversion (colour development) was measured at 565 and $690 \mathrm{~nm}$ using a plate reader. The readings at $690 \mathrm{~nm}$ were used to correct for the increase in turbidity due to growth of the yeast. Samples were tested in quadruplicates, and a standard curve for E2 or DHT $\left(10^{-12}-10^{-8} \mathrm{M}\right)$ was included in each assay. The concentration of the test oils was ranged from $10^{-8}$ to $5.10^{-6}$.

\section{Luciferase-reporter-gene assay}

The MCF-7 human breast cancer cell line is a well-established in vitro model characterized by its estrogen responsiveness. It has been frequently used to test the effects of Estrogen mimics on the pathway(s) linking estrogen receptor binding to gene expression and cell proliferation. This investigation tested the effects of $C$. procera seeds oils on this cell line to evaluate their estrogenic activity. MVLN cell line is based on human MCF-7 cells containing an estrogen regulated luciferase reporter gene driven by an ERE of the vitellogenin A2 gene fused to the thymidine-kinase-promoter (Gagne et al., 1992; Pons et al., 1992). Therefore, the specific transcription activity of a test chemical is directly related to the activity of luciferase measured. MVLN cells were maintained as previously described (Pons et al., 1992). On the day of induction, the medium was changed against fresh $1 \%$ DCC-FCS medium and cells were treated with the test compounds $\left(10^{-10}-10^{-}\right.$ ${ }^{5} \mathrm{M}$ ), or $17 \beta$-estradiol (positive control), and vehicle (DMSO). After $24 \mathrm{~h}$, cells were harvested and treated for luciferase assay. The luciferase was extracted as described (Pons et al., 1992). To compare data, the protein content of each extract was measured using the bicinchoninic acid (BCA) protein assay, with bovine serum albumin (BSA) as standard protein. Luciferase activity was calculated in relative light units (RLU) per $\mathrm{mg}$ of protein.

\section{Statistical analysis}

The results are expressed as mean \pm Standard Deviation. ANOVA I followed by a 
post hoc multiple comparison was performed. Dunnett's test (SPSS version 20) was used to compare increasing doses of the test compounds with the respective control. Pvalues $<0.05$, were considered significant. The PHARMS/PC was used for the determination of the LD50.

\section{RESULTS}

\section{Chemical composition}

The phytochemical screening on $C$. procera seeds revealed the presence of steroidal glycosides, triterpene, flavonoids, tannins, leucoanthocyanins and alkaloid in the $\mathrm{MeOH} / \mathrm{H}_{2} \mathrm{O}$ fraction. In the dichloromethane (DCM) extract triterpene esters \& steroid, carotenoids and fatty acid with high molecular weight were detected (Table 1). All biological activities were carried out with hydro-alcoholic extracts.

\section{Acute and subchronic toxicity}

After $72 \mathrm{~h}$ observation, the LD50 and the report LD50/LD1, LD99/LD50 values were respectively $815,2.90$, and 2.90 . The security index DL99/DL1 value was 8.41 (Table 2).

For subacute toxicity, all mice survived till the end of 28 consecutive days' treatment. The signs of abnormalities and behavior observed were ruffled hair, sneezes, somnolence, loss of mobility and anorexia. In the two groups, the feces had not significantly changed. C. procera hydroalcohol seeds extracts showed $4.96 \%$ of body weight decrease compare with the control group. Compare with control group, the weight of lungs, heart, liver, kidney and spleen had not significantly $(\mathrm{p}>0.05)$ changed.

\section{Brine shrimp lethality assay}

C. procera seeds hydroalcohol extracts, press and hexane oils were found to be potent against Brine Schrimp with LC50 value 219, 333, $641 \mu \mathrm{g} / \mathrm{ml}$ respectively (Table 3).

\section{Estrogenic activity}

On the average daily weight gain of female mice, the different doses of $C$. procera hydro-alcohol seeds extracts did not show a significant $(\mathrm{p}>0.05)$ effect compare with control groups DMSO (1\%) and (Figure 1).

The doses of 50 and $100 \mathrm{mg} / \mathrm{kg}$ of $C$. procera hydro-alcohol seed extracts were exhibited a significant $(\mathrm{p}<0.05)$ increase on the uterus weight of mice respectively at 58 and $74 \%$ compare with the control group (Figure 2).

\section{Androgenic activities}

The different treatments did not have a significant $(\mathrm{P}>0.05)$ effect on the male average daily weight gain compare to control groups (Figure 3). Therefore, on seminal vesicle, prostate and Levator Ani and Bulbocanernous Muscle (LABC), $100 \mathrm{mg} / \mathrm{kg}$ of $C$. procera seeds extract induced a significant $(\mathrm{p}<0.05)$ decrease of these gland compare to control groups (Figure 5).

\section{Estrogen yeast assay and androgenic yeast assay}

The estrogenic and androgenicity activities of C. procera seeds extracts were examined by growing the yeast strain overnight in the presence of vehicle, $17-\beta$-estradiol or the different doses of $C$. procera seeds extracts and measuring $\beta$-galactosidase activity. Estradiol and DHT (Dihydrotesterone) were the most effective compounds tested inducing maximal $\beta$-galactosidase activity. $C$. procera seeds extracts did not exhibit estrogenic or androgenic activities (Figure 6).

\section{Luciferase-reporter-gene assay}

Luciferase induction was analysed after $24 \mathrm{~h}$ incubation of MVLN cells with 0.001 , $0.01,0.1 \mu \mathrm{g} / \mathrm{ml}$ of $C$. procera seeds oil extracts. E2 at $10^{-8} \mathrm{M}$ was used as a positive control and DMSO as a negative control. The different doses of $C$. procera seeds oil extracts show a significant $(\mathrm{p}>0.05)$ dose dependent luciferase induction (Figure 7). 
Table 1: Chemicals composition of $C$. procera extracts.

\begin{tabular}{|c|c|c|c|}
\hline \multirow{3}{*}{ CHEMICAL GROUPS } & \multicolumn{3}{|c|}{ EXTRACTIONS } \\
\hline & \multirow[t]{2}{*}{ DCM } & \multicolumn{2}{|c|}{$\mathrm{Meth} / \mathrm{H}_{2} \mathrm{O}$} \\
\hline & & $\begin{array}{c}\text { Hydrolyzed extract } \\
\text { (aglucones) }\end{array}$ & $\begin{array}{l}\text { Unhydrolyzed extract } \\
\text { (glycosides) }\end{array}$ \\
\hline Triterpene esters \& steroid & $\begin{array}{l}++(\mathrm{r}-\mathrm{br}): \text { triterpenes } \\
\text { and phytosterols }\end{array}$ & ND & ND \\
\hline Flavonoid aglycone & ND & ND & ND \\
\hline Alkaloid bases & + (Dragendorff) & ND & ND \\
\hline Coumarins & ND & ND & ND \\
\hline Carotenoids & + & ND & ND \\
\hline $\begin{array}{c}\text { Fatty acids of high } \\
\text { molecular } \\
\text { weight }\end{array}$ & + & ND & ND \\
\hline $\begin{array}{l}\text { Steroidal glycosides \& } \\
\text { triterpene }\end{array}$ & ND & $\begin{array}{c}++(\text { r-br }): \\
\text { Phytosterols }\end{array}$ & ND \\
\hline Flavonoids & ND & ++ (red) : flavonols & ND \\
\hline Anthraquinone & ND & ND & ND \\
\hline Leucoanthocyanins & ND & ++ & ND \\
\hline Tannins & ND & ND & ++ (blue) : gallic \\
\hline saponosides & ND & ND & $+($ suds height $>1,5 \mathrm{~cm})$ \\
\hline alkaloid salts & ND & ND.. & + (Dragendorff) \\
\hline
\end{tabular}

Table 2: Lethal doses (LD) (mg/kg) after $72 \mathrm{H}$ of $C$. procera extracts on mice.

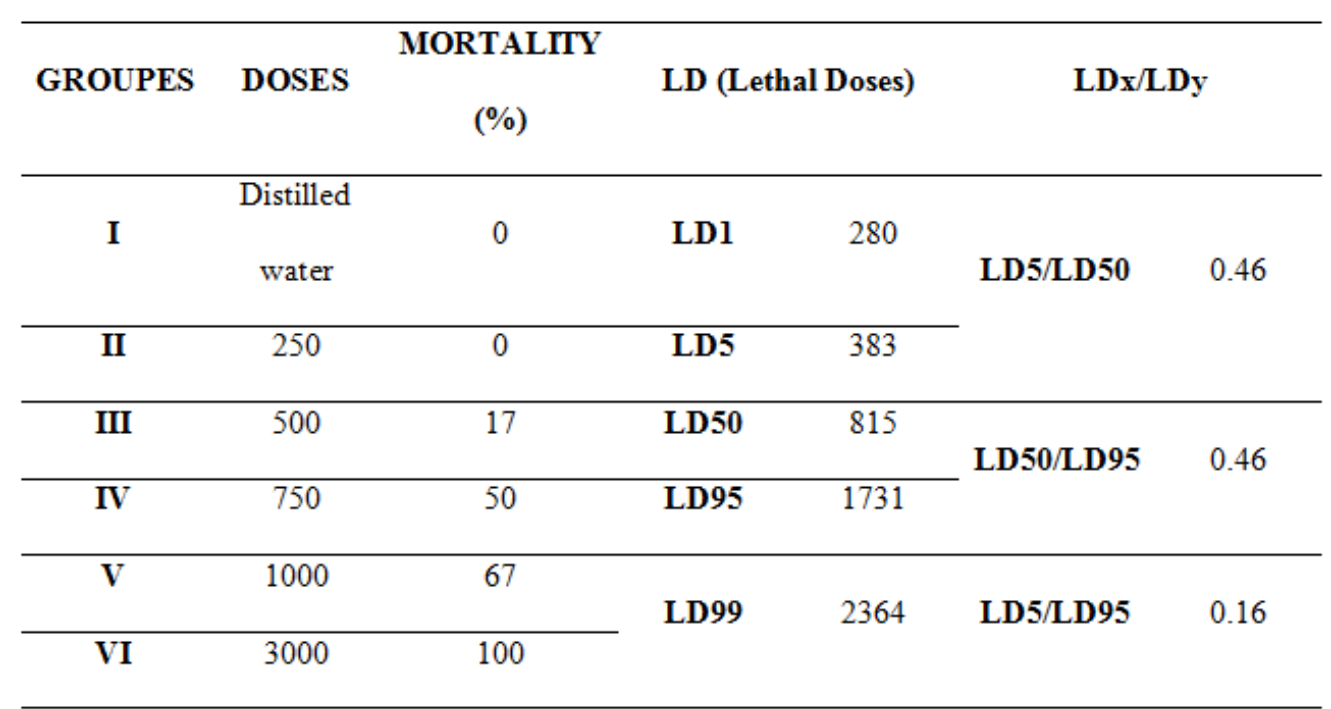


Table 3: Effects of C. procera seed extracts and oils on Brine shrimp lethality.

\begin{tabular}{|c|c|c|c|c|c|c|}
\hline \multirow{2}{*}{ Plants } & \multirow{2}{*}{ Material } & \multicolumn{4}{|c|}{ Percent $(\%)$ death at $24 \mathrm{H}$} & \multirow{2}{*}{$\begin{array}{r}\mathrm{LC50} \\
(\mu \mathrm{g} / \mathrm{ml})\end{array}$} \\
\hline & & $1 \mu \mathrm{g} / \mathrm{ml}$ & $10 \mu \mathrm{g} / \mathrm{ml}$ & $100 \mu \mathrm{g} / \mathrm{ml}$ & $\begin{array}{c}1000 \\
\mu \mathrm{g} / \mathrm{ml}\end{array}$ & \\
\hline \multirow{3}{*}{ C. procera } & Seed & 0 & 1 & 5 & 70 & 219 \\
\hline & Press oil & 0 & 0 & 8 & 63 & 333 \\
\hline & Hexane oil & 0 & 0 & 0 & 48 & 641 \\
\hline
\end{tabular}

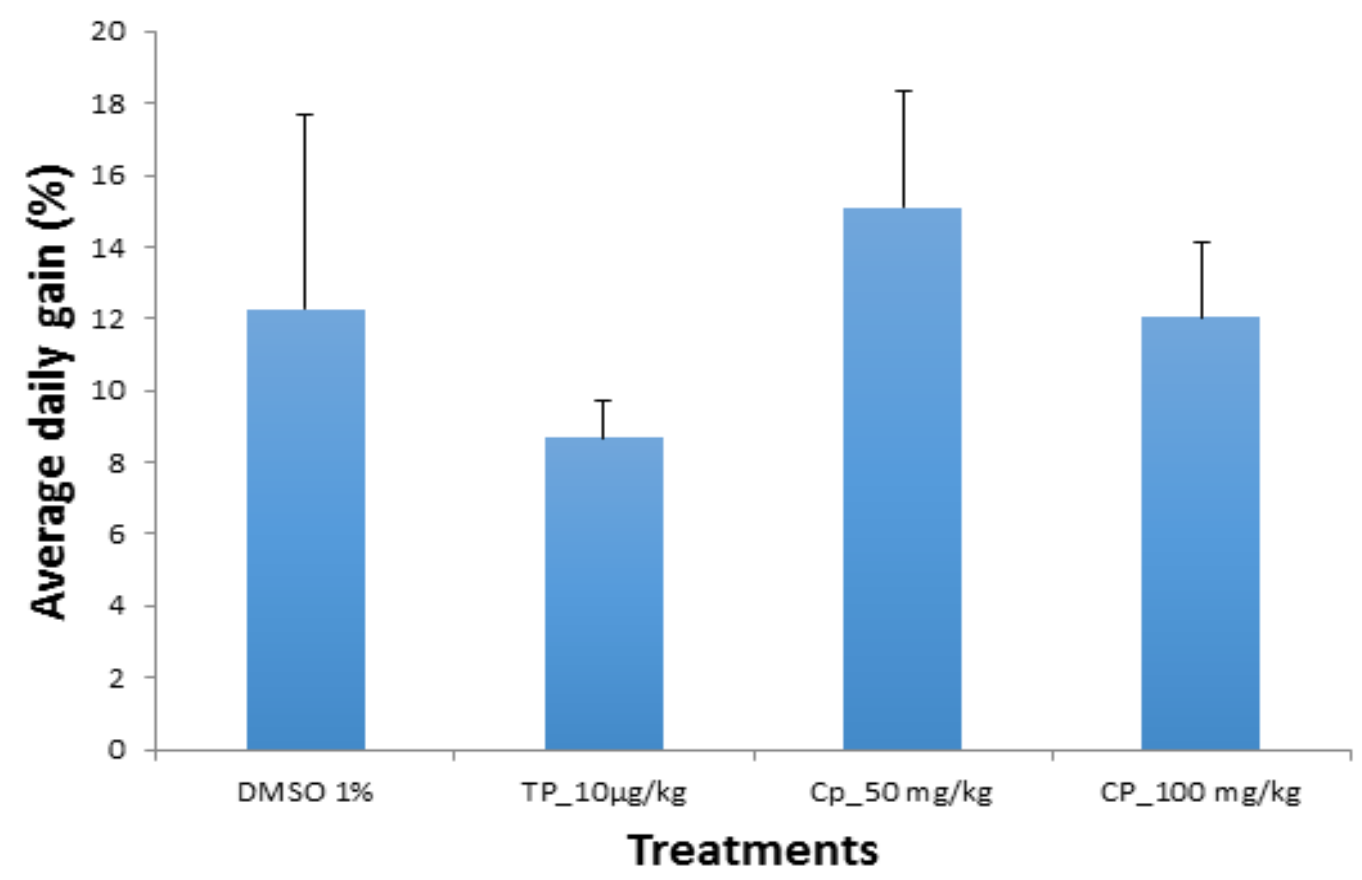

Figure 1: Effect of treatments on average daily gain of female mice. Each histogram represents the mean \pm SEM of the values for 5 animals. 


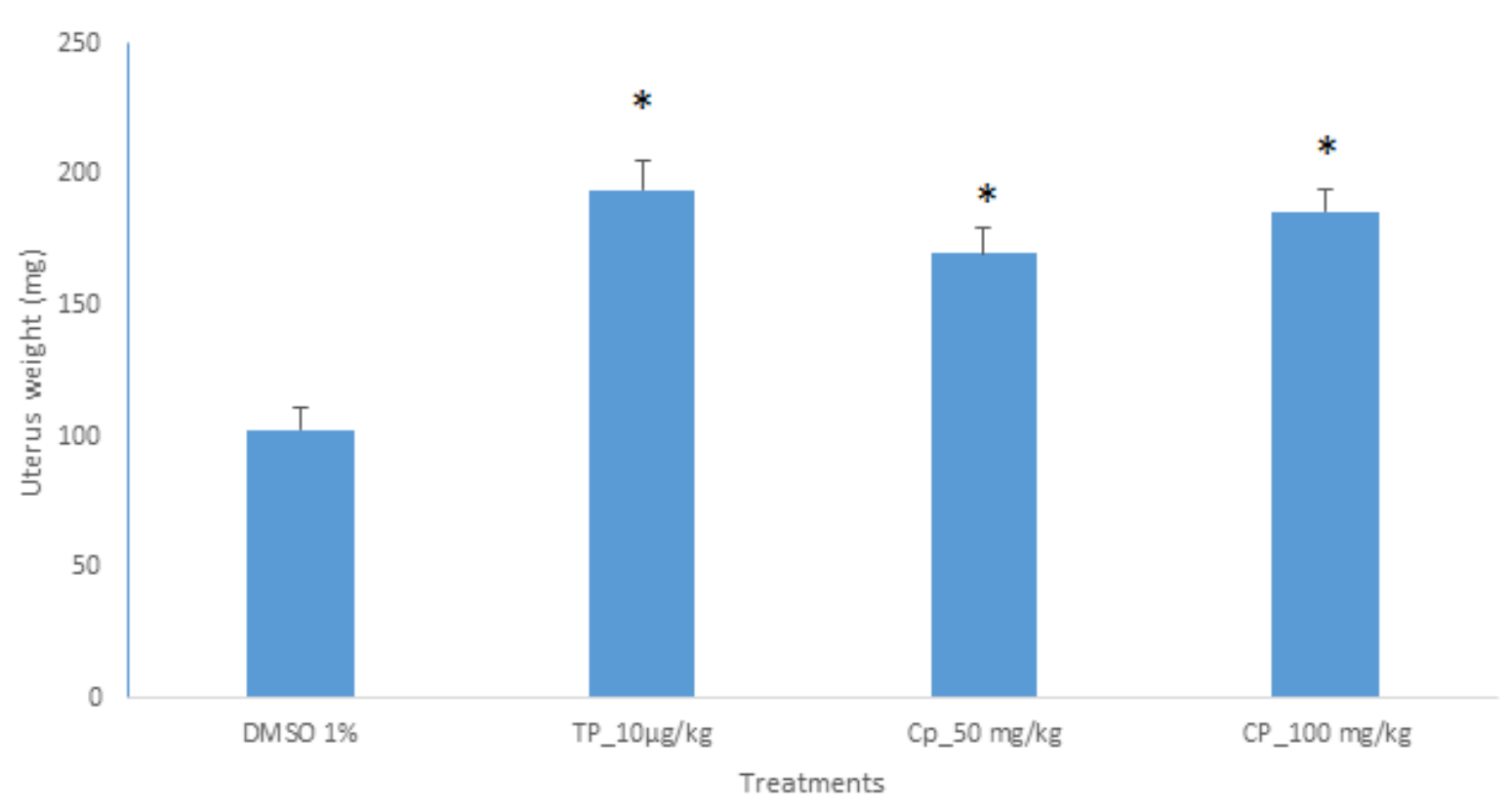

Figure 2: Effect of treatments on uterus weight. * ${ }^{*}<0,05$ (Values significantly different from those of the control group (ANOVA and Dunnett's test); each histogram represents the mean \pm SEM of the values for 5 animals.

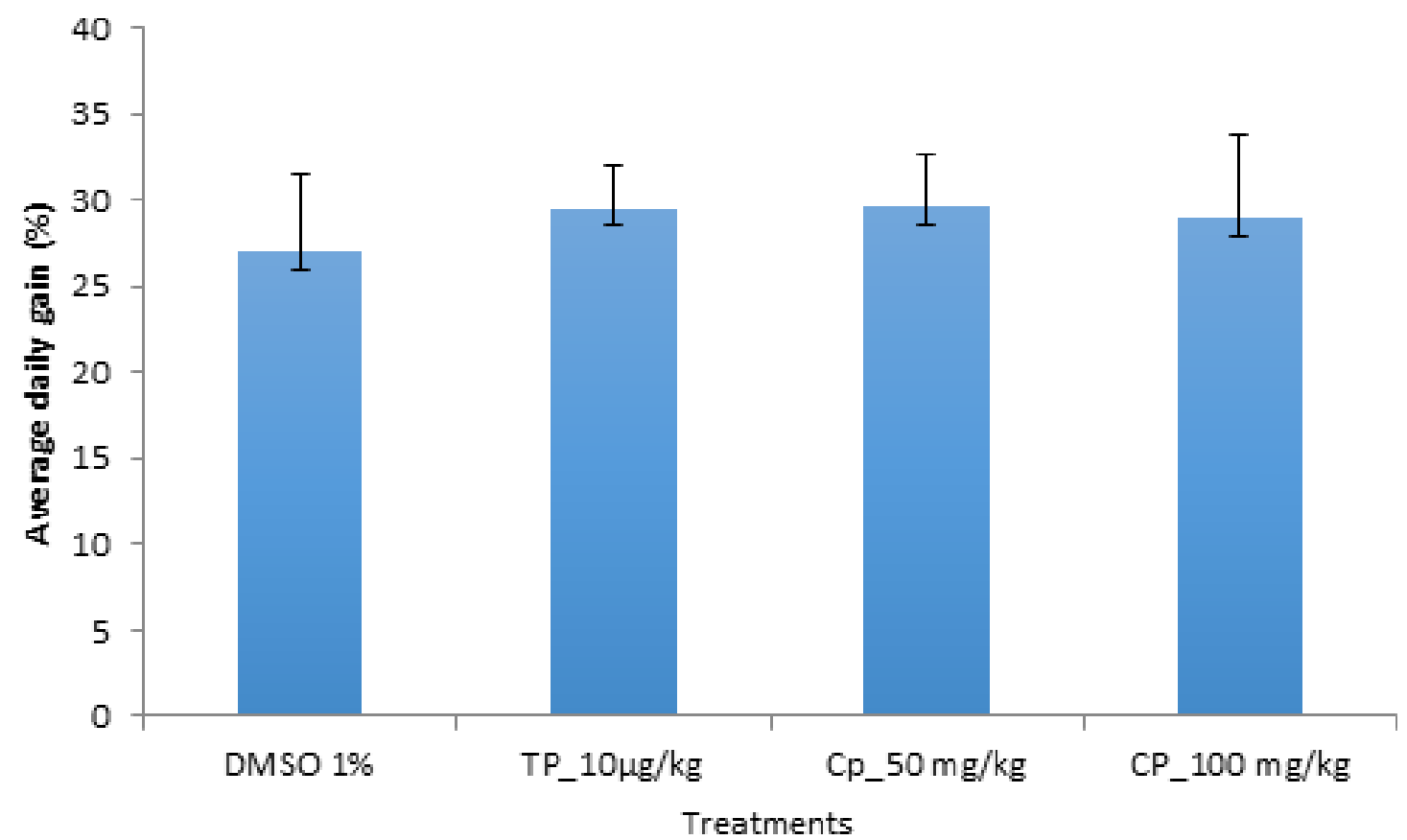

Figure 3: Effect of treatments on the average daily weight gain of female mice. Each histogram represents the mean \pm SEM of the values for 5 animals. 


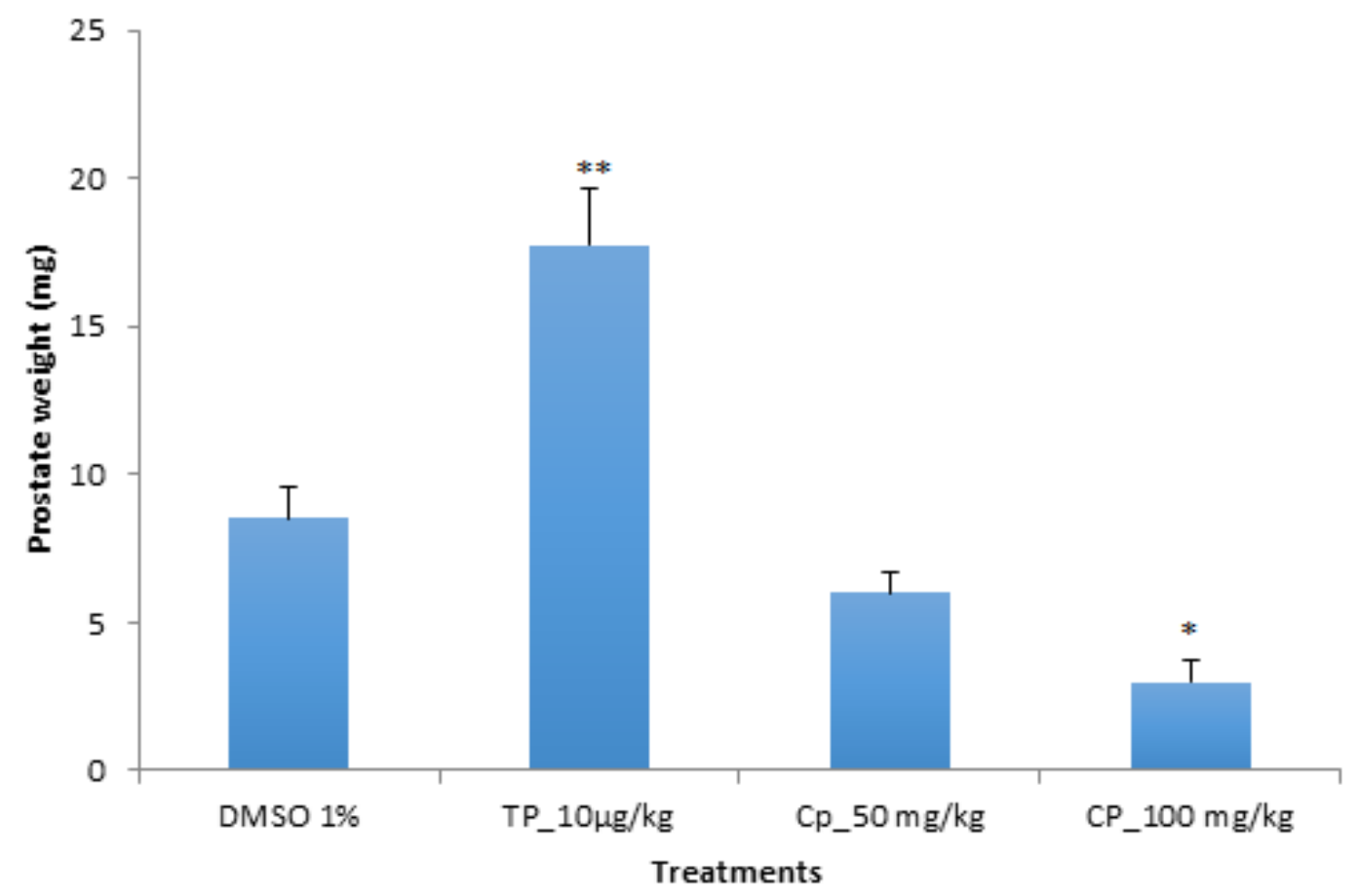

Figure 4: Effect of treatments on the evolution of prostate weight. ${ }^{*} \mathrm{p}<0.05,{ }^{*} \mathrm{p}<<0.01$ (Values significantly different from those of the control group (ANOVA and Dunnett's test); each histogram represents the mean \pm SEM of the values for 5 animals).

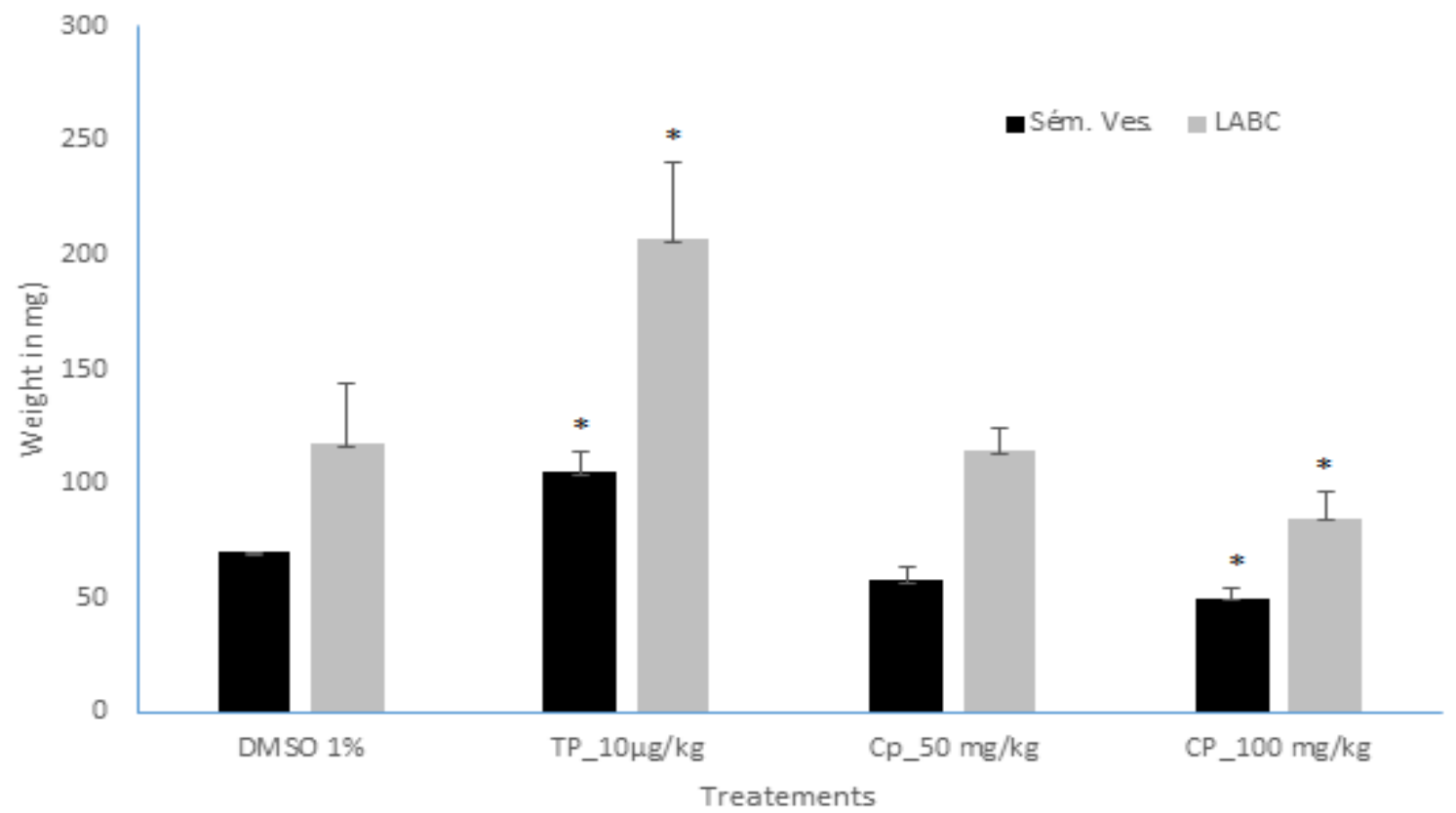

Figure 5: Effect of treatments on seminal vesicles and LABC weight. ${ }^{*} p<0,05$ (Values significantly different from those of the control group (ANOVA and Dunnett's test); each histogram represents the mean \pm SEM of the values for 5 animals). 


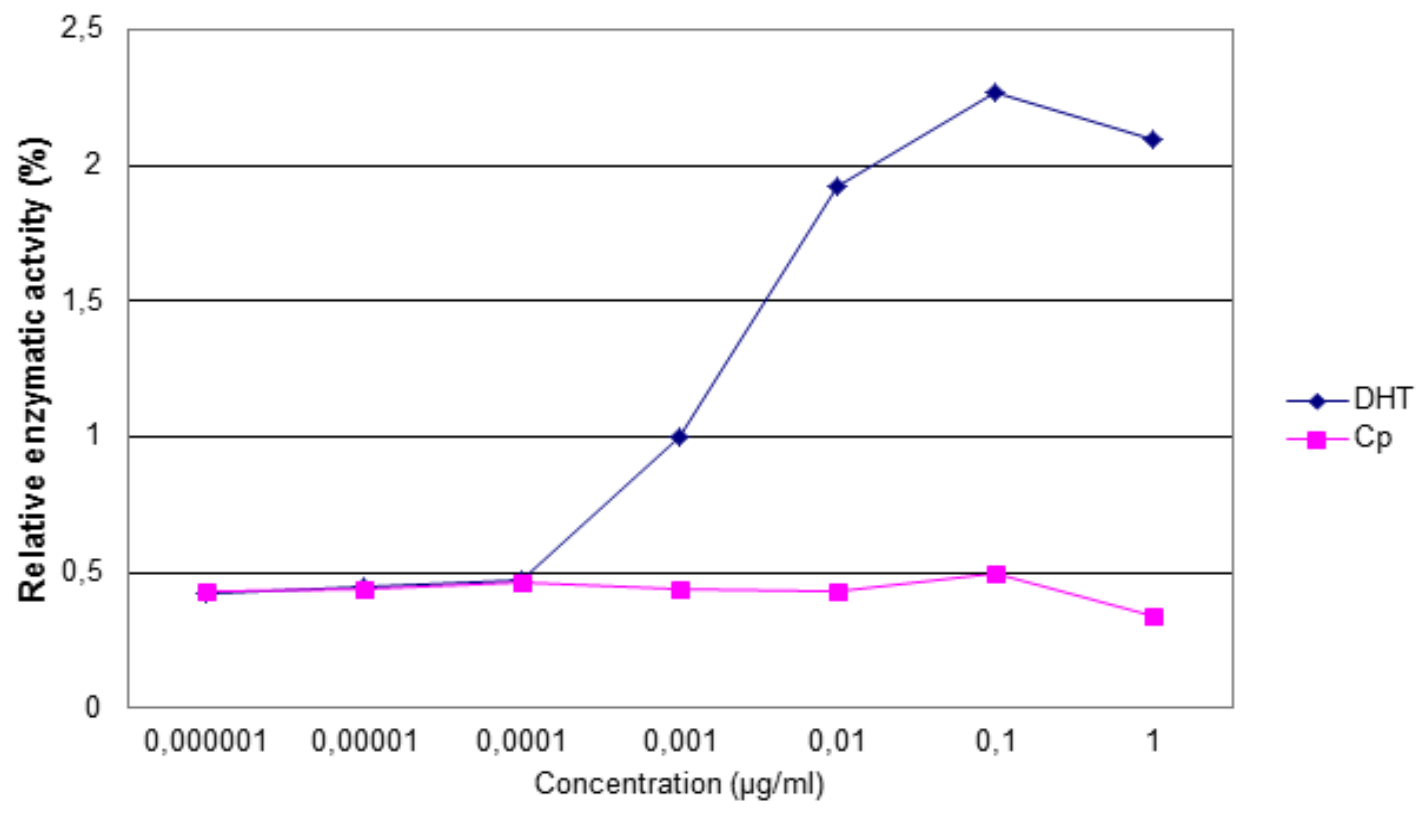

Figure 6: Androgen inducible yeast receptor assay. Androgen potential of $\mathrm{Cp}$ seed extracts were tested in concentration dependent manner. The recombinant yeasts were incubated at $32{ }^{\circ} \mathrm{C}$ for $48 \mathrm{~h}$ with test compounds. Data represent the mean \pm SEM of Three independent experiments (Cp: Carapa procera; DHT: Dihydrotesterone).

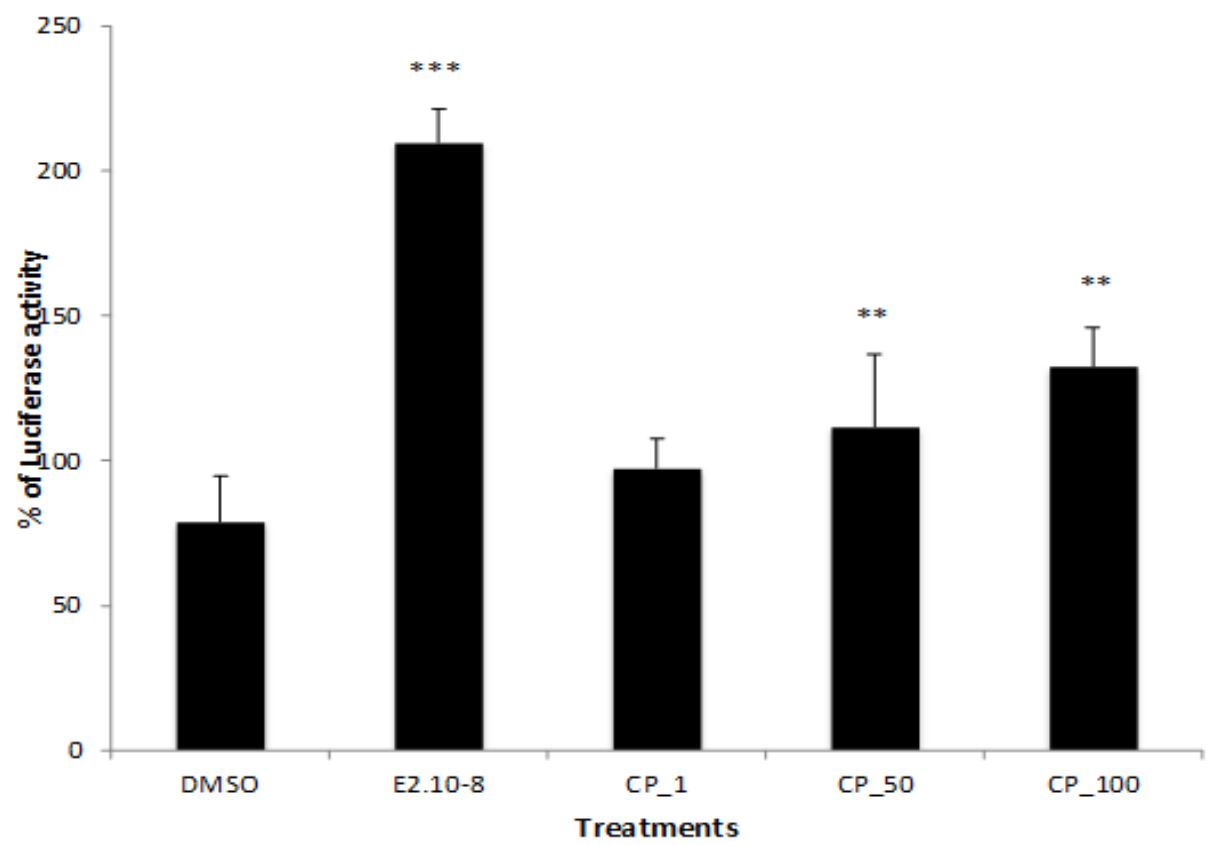

Figure 7: Effect of Cp seed oils extracts on luciferase induction. MVLN cells were exposed to substances for $24 \mathrm{~h}$ at 1,10 and $100 \mathrm{mg} / \mathrm{kg}(0,001,0,01 ; 0,1 \mu \mathrm{g} / \mathrm{ml})$. E2 $\left(10^{-8} \mathrm{M}\right)$ was used as standard agonist. All the substances were dissolved in DMSO. Each concentration was tested in duplicate. DMSO $(0.1 \%)$ was used as control. $* * \mathrm{p}<0,01, * * * \mathrm{p}<0,001$, significantly different from the control group (ANOVA I followed by a post hoc multiple comparison). 


\section{DISCUSSION}

The seeds of $C$. procera are widely used by women in rural communities for oil extraction. This oil, which is highly appreciated for its nutritional, cosmetic and medical qualities, allows women to increase their incomes and thus reduce their poverty (Weber et al., 2009). Although several studies have focused on $C$. procera oil, very little data exist on the biological activities evaluation of C. procera seeds extracts.

The phytochemicals screening of $C$. procera seeds have showed the presence of carotenoids, triterpens esters, steroid and alkaloid in DCM extracts. In hydro-alcohol extracts the screening shows the presence of steroidal glycosides and triterpens, flavonoids, leucoanthocyaninis, polyphenols and saponosides. The presence of flavonoids and triterpens explain why these extracts are used for biological activities evaluation.

The presence in $C$. procera seeds of flavonoids as flavonols are considered as beneficial phytoestrogens for the resolution of deficiencies of estrogen in humans and animals physiology (Martinez, 2012) and triterpenic and steroidic glycosides such as phytosterols are considered asphyto-androgen for testosterone synthesis.

The LD50 of $C$. procera hydro- alcoholic extract is classified in the scale of Hodge and Sterner (1943) as slightly toxic and in class II described as moderately dangerous according to the scale of OMS. These results are similar with those of Lompo et al. (1995) which indicated a low toxicity in mice of the extract of Kaya senegalensis, a plant from the same family (Meliaceae) as $C$. procera.

The equal ration of LD5/LD50 and LD50/LD95 confirm the validily of our LD50 test values (Somé et al., 1996). The quotient $\mathrm{DL}_{5} / \mathrm{DL}_{95}$ indicates a value of 0.16 more inferior to 1 . It means that $C$. procera hydroalcohol extract is safe of use and have a large marge of maneuverability (Hodge and Sterner, 1943). C. procera seeds for therapeutic use should be made with caution for its low toxicity. The extract probably contains toxic substances that could cross the intestinal barrier and pass in the blood and cause damage to vital organs.

This is the case of tannins which can easily infiltrate the blood and body tissues when they are consumed in excess. Intraperitoneal administration of $C$. Procera hydro-alcoholic extracts even if it has a low toxicity can provoke failures of vital organs and a decrease of body.

The brine shrimp mortality assay is widely accepted as a convenient probe for potential pharmacological activity (Meyer et al., 1982). Toxic constituents of plant extracts showing lethal effects against the crustacean larvae may elicit interesting effects at lower, non-toxic doses (McLaughlin, 1991; 1993). According to Meyer et al. (1982) extracts derived from natural products, which have LC50 $\leq 1000 \mathrm{mg} / \mathrm{mL}$ are known to possess toxic effects. Hence the seeds of $C$. procera were more toxic than press and hexane oils. In the most cases, toxicity is associated with pharmacological properties, it was concluded that $C$. procera seeds can have best bioactivity (Wanyoike et al., 2004). This result is similar to those obtain by in vitro with acute toxicity test.

C. procera's hydro-alcoholic seeds extracts as well as 17- $\beta$ estradiol caused a significant increase of the weight of uterus but did not have significant effect on the weight of animals. These results have confirmed some works (Cruz et al., 2017) which have indicated that the administration of estradiol can allow, during four months, the weight loss of female before they find their normal weight. The increase of the weight of uterus, an estrogen dependent gland, suggests that the extracts of C. procera contain various secondary metabolites, which can have estrogenic activity.

In fact, the phytochemical screening $\mathrm{MeOH} / \mathrm{H}_{2} \mathrm{O}$ extracts of $C$. procera showed that it contain flavonoids, flavonol, steroidal glycosides and polyphenols which can explain this estrogenic activity (Hodek et al., 2002; Bayala, 2005). It is well known that some chemical features in the structure of flavonoids are required to obtain an estrogenic response (Choi et al., 2008) and the hydroxyl group at position $4^{\prime}$ promotes the estrogenic activity and the estrogenic potency (Zand et al., 2000; Zingue et al., 2016). The increase of the uterus weight can be explained by the effect of flavonoids on estrogen receptor and induced a proliferation of cells of endometrium as indicated by Kouakou et al. (2008) and Benneteau-Pelissero (2010). The discovery of ER $\beta$, the second ER, by Kuiper et al. (1996) was the most significance for the understanding of estrogen action. Some compounds of plant origin have been demonstrated to bind with higher affinity to this type of receptor than to ER $\alpha$ (yeast assay ERalpha) (Kuiper et al., 1998). The other important, which can explain estrogen action was the discovery of co-activators (Onate et al., 1995) and co-repressors (Lavinsky et al., 1998), which are involved in the initiation and regulation of gene transcription by the ER. Such co-activators are believed to determine the agonistic and antagonistic properties of compounds and to be responsible for the tissue specific action of selective estrogen receptor modulators (SERMs).

For Hershberger test, the hydro- alcoholic extracts of $C$. procera seeds are showed a significant decrease of the weight of prostate, seminal vesicle and levator ani muscle. All these glands are androgen dependent organs. These results reveal that the extracts of $C$. procera can contain some 
chemical components which are possessing antiandrogenic activities. These results could explain the estrogenic effects of $C$. procera extracts because flavonoids are also known to produce antiandrogenic activity and affect male fertility (Bhargava, 1989). The antiandrogenic activity of $C$. procera extract is probably due to the estrogenic activity of flavonoids. A potent anti-androgen can create an estrogenic activity (Sohoni and Sumpter, 1998) and inhibit alpha reductase (Liang and Liao, 1992; Blanchard and Robaire, 1997).

Although the Uterotrophic and Hershberger assays in rodents are a good tool to assess estrogenic/antiestrogenic and androgenic/ antiandrogenic potency of natural products, these methods are not suitable for the screening of large suspected estrogenic/androgenic chemicals (Kornera et al., 1999).

The yeast assay did not show an estrogenic and androgenic effects when compare to control group. Therefore, the luciferase activity of MVLN cells incubated with various concentrations of $C$. procera extracts exhibit as 17- $\beta$-estradiol a significance increase of luciferase induction. These results confirm the estrogenic activity obtain with the uterotrophic assay. The luciferase activity induced by $C$. procera seeds extracts can be due to an estrogen-like receptor compound that bound and activated the receptor (Le Bail et al., 1998).

The fact that $C$. procera extracts show an estrogenic activity in uterotrophic assay and antiandrogenic activity with Hershberger assay can be explained by the complexity of sex hormones actions. Sex hormones like, estrogen and androgen generally act by binding at receptor sites and a synthetic chemical can disrupt this way by number of mechanisms. A chemical may mimic the action of the natural ligand by being able to act on this receptor site, or it may interfere with the receptor in some other way, and be able to block the action of the hormone (Iguchi, 1992). For example o,p-DDT, which was shown originally to be a weak estrogen, also possesses anti-androgenic activity ( Kelce et al., 1995).

Some chemicals can also perturb the normal functioning of the sex hormones by inhibiting the enzymes responsible for steroid hormone biosynthesis and/or inducing enzymes responsible for steroid metabolism (Majdic et al., 1996).

\section{Conclusion}

C. procera seeds extracts has for in vivo tests slighty toxic effects and show a lethal effects against the crustacean larvae by in vitro tests. The seeds extracts of $C$. procera has also an estrogenic and anti-androgenic properties due its high amount of flavonoids, glycosides steroids and triterpernoids. Phyhormones still need evaluating for their safety on human systems, beneficial and harmeful doses. This estrogenic effect has been confirmed by the luciferase activity of MVLN cells incubated with various concentrations of $C$. procera. The uses of $C$. procera seeds for oils extraction need to pay more attention to the extraction system to prevent endocrine disrupting substances from passing through the oil. However, further studies have to be developed to achieve a better understanding regarding the interactions between the ligandreceptor binding of these compounds and ERs.

\section{COMPETING INTERESTS}

The authors declare that they have no competing interest.

\section{AUTHORS' CONTRIBUTIONS}

This work was carried out in collaboration between all the authors. The collection and the identification of the seeds of $C$. procera were done by BB, SB and HHT. VM, OY participated in the extraction and phytochemical screening. In vivo and in vitro tests were made by $\mathrm{BB}, \mathrm{SB}$ and VM. The obtained results were statistically analyzed by $\mathrm{BB}$ and SB. The supervision of the works was made by HHT and BB. All the authors read and approved the final manuscript.

\section{REFERENCES}

Bayala B. 2005. Activité progestative et activité oestrogénique de Holarrhena floribunda (G. Don) Durand et Schinz (Apocynaceae), une plante de la pharmacopée traditionnelle du Burkina Faso. Thèse de Doctorat Sciences Biologiques Appliquées, Université de Ouagadougou. 93 pages.

Bennetau-Pelissero C. 2010. Phyto-œstrogènes et santé : bénéfices et inconvénients. Lettre Scientifique IFN., 143 : 1-16.

Bhargava SK. 1989. Antiandrogenic effects of a flavonoid rich fraction of Vitex negundo seeds: A histological and biochemical study in dogs. $J$ Ethnopharmacol., 27(3): 327-39. DOI: 10.1016/0378-8741(89)90007-X

Blanchard Y, Robaire B. 1997. Le mode d'action des androgènes et la $5 \alpha$-réductase. Médecine/Science. 13(4): 467-473.

Bruce RD. 1985. An up-and-down procedure for acute toxicity testing. J. Fund. Appl. Toxicol., 5 : 151-157.

Choi SY, Ha TY, Ahn JY, Kim SR, Kang KS, Hwang IK, Kim S. 2008. Estrogenic activities of isoflavones and flavones and their structureactivity relationships. Planta Med., 74 : 25-32. DOI: 10.1055/s-2007-993760.

Cruz G, Fernandois D, Paredes A. 2017. Ovarian function and reproductive senescence in the rat: role of ovarian sympathetic innervation. 
Reproduction., 153 : R59-R68. DOI: 10.1530/REP-16-0117

Diel P, Schmidt S, Vollmer G. 2002. In vivo test systems for the quantitative and qualitative analysis of the biological activity of phytoestrogens. Journal of Chromatography B., 777 : 191-202. DOI: 10.1016/S15700232(02)00494-4

Gagne D, Pons M, Balaguer P, Nicolas JC. 1992. Bioluminescence and creation of chimeric cellular models. C.R. Seances Soc. Biol. Fil., 186 : 528-540.

Goubgou M. 2013. Composition et physico-chimie des graines et des matières grasses de trois plantes oléagineuses du Burkina. Mémoire de Maitrise. Université de Ouagadougou. UFR/SVT. 35 pages.

Guillemot N. 2004. Le Carapa, un arbre tropical aux intérêts écologiques et économiques prometteurs. Rapport de stage. Institut national agronomique Paris-Grignon. 23 pages.

Hodek P, Trefil P, Stibozova M. 2002. Flavonoids potent and versatile biologically active compounds interacting with cytochromes P450. Chim. Biol. Interactions., 139 : 1-21. DOI: 10.1016/S0009-2797(01)00285-X

Hodge H, Sterner J. 1943. Determination of substances acute toxicity by LD50. American Industrial Hygien Association. 93 pages.

Iguchi T. 1992. Cellular eVects of early exposure to sex hormones and anti-hormones. International Review of Cytology-A Survey of Cell Biology, 139 : $1-57$.

Kelce WR, Stone CR, Laws SC, Gray LE Jr., Kemppainen J, Wilson EM. 1995. Persistent DDT metabolite pp-DDE is a potent androgen receptor antagonist. Nature, 375 : 581-585. DOI: 10.1038/375581a0

Kornera W, Hanf V, Schuller W, Kempter C, Metzger J, Hagenmaier H. 1999. Development of a sensitive E-screen assay for quantitative analysis of estrogenic activity in municipal sewage plant effluents. Sci Total Environ., 225 : 33-48. DOI : 10.1016/S0048-9697(99)800151

Kouakou K, Benie T, Thieulant ML. 2008. Effets œstrogène-like des extraits de Dadinia concentrica et de Psathyrella efflorescens au niveau moléculaire. Phytothérapie, 6(3) : 165174.

Kuiper GGJM, Enmark E, Pelto-Huikko M, Nilsson S, Gustafsson J-A. 1996. Cloning of a novel estrogen receptor expressed in rat prostate and ovary. Proc Natl Acad Sci USA, 93: 59255930.

Kuiper GGJM, Lemmen JG, Carlsson B. 1998. Interaction of estrogenic chemicals and phytoestrogens with estrogen receptor. Endocrinology, 139 : 4252-4263. DOI: 10.1210/endo.139.10.6216

Lavinsky RM, Jepsen K, Heinzel T, Torchia J, Mullen TM, Schiff R, Del-Rio AL, Ricote M, Ngo S, Gemsch J, Hilsenbeck SG, Osborne CK, Glass CK, Rosenfeld MG, Rose DW. 1998. Diverse signaling pathways modulate nuclear receptor recruitment of $\mathrm{N}-\mathrm{CoR}$ and SMRT complexes. Proc Natl Acad Sci U S A., 95(6) : 2920-2925. The National Academy of Sciences $\quad 0027-8424 \quad 98 \quad 952920-6 \$ 2.00 \quad 0$ PNAS is available online at http: www.pnas.org.

Le Bail JC, Marre-Fournier F, Nicolas JC, Habrioux G. 1998. C19 Steroids activity in human breast cancer cell lines: Importance of dehydroepiandrosterone sulfate at physiological plasma concentration. Steroids, 63 : 678-683. DOI: 10.1016/S0039128X(98)00078-6

Liang T, Liao S. 1992. Inhibition of steroid 5 alpha reductase by specific aliphatic unsaturated fatty acids. Biochemical Journal, 285 : 557-562. DOI: $10.1042 / \mathrm{bj} 2850557$

Lichtfield JT, Wilcoxon F. 1949. A simplified method of evaluation of doses- effects experiments. J. Pharmacol. Exp. Ther., 95: 99113.

Lompo M, Guissou I, Kaboré I, Sawadogo M. 1995. Effet hypo-thermisant et toxicité générale aigüe chez les souris des écorces de tronc de Kaya senegalansis. Pharm. Méd. Trad. Afro.: 73-80.

Majdic G, Sharpe RM, O'Shaughnessy PJ, Saunders PTK. 1996. Expression of cytochrome P450 17.-hydroxylase/C17-20 lyase (P450c17) in the fetal rat testis is reduced by maternal exposure to exogenous oestrogens. Endocrinology, 137: 1063-1070. DOI: 10.1210/en.137.3.1063

Martinez. 2012. Les isoflavones de soja diminuent le taux de testostérone. www.wikipedia.org., 28/10/2012.

McLaughlin JL. 1991. Methods of Plant Biochemistry, Hostettmann K (ed.). Academic Press: London; 6 : 1-32.

Meyer BN, Ferrigni NR, Putnam JE, Jacobsen LB, Nichols DE, McLaughin JL. 1982. Brine Schrimp: a convenient general bioassay for active plant constituents. Planta Medica., 45 : 31-34. DOI: $10.1055 / \mathrm{s}-2007-971236$

OECD 2001. Test Guideline 425, Acute Oral Toxicity - "Up and Down Procedure", adopted 17th December.

Onate SA, Tsai SY, Tsai MJ, O'Malley BW. 1995. Sequence and characterization of a co-activator for the steroid hormone receptor superfamily. 
Science, 270: 1354-1357. DOI: 10.1126/science.270.5240.1354

Ouédraogo A, Lykke AM, Lankoandé B, Korbéogo G. 2013. Potentials for Promoting Oil Products Identi ed from Tradi- tional Knowledge of Native Trees in Burkina Faso. Ethno- botany Research Applications, 11 : 71-83.

Pons M, Chabret C, Demirpence E, JausonsLoffreda N, Gagne D. 1992. Using examples of firefly luciferase gene for the study of biological activities (estrogens, retinoids, phorbol esters). C.R. Seances Soc. Biol. Fil., 186 : 550-559.

Routledge EJ, Sumpter JP. 1997. Structural features of alkylphenolic chemicals associated with estrogenic activity. J. Biol. Chem., 272 : 32803288. DOI: $10.1074 /$ jbc.272.6.3280

Sohoni P, Sumpter JP. 1998. Several environmental oestrogens are also anti-androgens. Journal of Endocrinology. 158:158 : 327-339. doi: 10.1677/joe.0.1580327

Somé N, Sawadogo L, Lompo M, Pousset JL, Guissou IP. 1996. Évaluation de la Toxicité générale aiguë d'un extrait aqueux de la poudre de racines de Tinosporabakis(A.RICH) Miers. (Mennispermaceae). Rev. Sci\& Tech. Série : Sciences de la Santé, 22(1): 38-46.

Tham DM, Gardner CD, Haskell WL. 1998. Clinical review 97: potential health benefits of dietary phytoestro- gens: a review of the clinical, epidemiological, and mechanistic evidence. J. Clin. Endocrinol. Metab. 83 : 2223-2235. DOI: 10.1210/jcem.83.7.4752

Tiétiambou FRS, Lykke AM, Korbéogo G, Thiombian A, Amadé Ouédraogo A. 2016. Perceptions et savoirs locaux sur les espèces oléagineuses locales dans le Kénédougou, Burkina Faso. Bois et Forêts des Tropiques, 327(1) : 39-50.
Tindo S, Valentine D, Felicien A, Paul L, Dominique K, Daniel P. 2012. Composition of Azadirachta indica and Carapa procera (Meliaceae) seeds oils and cakes obtained after oil extraction. Industrial Crops and Products, $38 \quad$ : $\quad 39-45 . \quad$ DOI: 10.1016/j.indcrop.2012.01.005

Wagner H, Bladt S. 2009. Plant Drug Analysis, a Thin Layer Chromatography Atlas ( $2^{\text {nd }}$ edn). Springer: Berlin. Germany.

Wanyoike GN, Chhabra SC, Lang'at-Thoruwa CC, Omar SA. 2004. Brine shrimp toxicity and antiplasmodial activity of five Kenyan medicinal plants. Journal of Ethnopharmacology, 90 : 129-133. DOI:10.1016/j.jep.2003.09.047

Weber N, Birnbaum P, Forget PM, Gueye M, Kenfack D. 2009. The oil of Carapa (Carapa spp. Meliaceae) in West Africa: uses and implications in the conservation of natural tree stands. Fruits, $\mathbf{6 5}(6)$ : 343-354. DOI: 10.1051/fruits/2010029

Zand RS, Jenkins DJ, Diamandis EP. 2000. Steroid hormone activity of flavonoids and related compounds. Breast Cancer Res Treat, 62 : 3549.

Zimmermann M. 1983. Ethical guidelines for investigations of experimental pain in conscious animals. Pain, 16: 109-110. DOI: 10.1016/0304-3959(83)90201-4

Zingue S, Michel T, Tchatchou J, Magne Nde CB, Winter E, Monchot A, Awounfack CF, Djiogue S, Clyne C, Fernandez X, Creczynski-Pasa TB, Njamen D. 2016. Estrogenic effects of Ficus umbellate Vahl. (Moraceae) extracts and their ability to alleviate some menopausal symptoms induced by ovariectomy in Wistar rats. $J$. Ethnopharmacol., $\mathbf{1 7 9}$ : 332-344. DOI: 10.1016/j.jep.2016.01.004. 